\title{
Association between Carcinoembryonic Antigen, Carbohydrate Antigen 19-9 and Body Mass Index in Colorectal Cancer Patients
}

\author{
Md. Salimullah Akand ${ }^{*}$, A. Z. M. Mostaque Hossain ${ }^{2}$, Md. Mohiuddin Aslam³
}

${ }^{\mathrm{I}}$ Assistant Professor, Department of Surgery, Shaheed Ziaur Rahman Medical College and Hospital, Bogura, Bangladesh

${ }^{2}$ Professor, Head of the Department (Surgery), Dhaka Medical College \& Hospital, Dhaka, Bangladesh

${ }^{3}$ Assistant Professor, Department of Ortho-surgery, Shaheed Ziaur Rahman Medical College and Hospital, Bogura, Bangladesh

DOI: $10.36347 /$ sjams.2020.v08i06.021

| Received: 01.06.2020 | Accepted: 17.06.2020 | Published: 21.06.2020

*Corresponding author: Md. Salimullah Akand

Abstract

Background: Carbohydrate antigen 19-9 (CA19-9) and carcinoembryonic antigen (CEA) have been well recognized as tumor markers for colorectal cancer. Previous studies suggested that body mass index is inversely associated with the screening of CEA and CA19-9 levels and may reduce screening sensitivity. Objective: To assess the relation between CEA \& CA 19-9 level and body mass index in colorectal carcinoma. Methods: A Prospective Observational Study was carried out at Department of Surgery, Dhaka Medical College Hospital (DMCH) from January, 2016 to December, 2016 (12 months). Cases were purposively selected according to inclusion criteria. Patients are divided group of on the basis of values of CEA level $<7 \mathrm{ng} / \mathrm{dl}$ and $\geq 7 \mathrm{ng} / \mathrm{ml}$, CA $19-9<37 \mathrm{ng} / \mathrm{ml}$ and $\geq 37 \mathrm{ng} / \mathrm{ml}$. Body mass index divided three groups which are $<18.5$, $18.5-24.0$ and $>24 \mathrm{~kg} / \mathrm{m}^{2}$. The quantitative observations were indicated by frequencies and percentages. P values $<0.05$ were considered as statistically significant. Results: Total 50 cases majority patients belonged to age 41-50 years in both groups (CEA $<7 \mathrm{ng} / \mathrm{ml}$ and $\geq 7 \mathrm{ng} / \mathrm{ml})$. The mean age was found $42.5 \pm 11.3$ years in CEA $(<7 \mathrm{ng} / \mathrm{ml})$ group and $40.7 \pm 12.1$ years in CEA $(\geq 7 \mathrm{ng} / \mathrm{ml})$ group. Male was found $15(40.5 \%)$ in CEA $(<7 \mathrm{ng} / \mathrm{ml})$ group and $06(46.2 \%)$ in CEA ( $\geq 7 \mathrm{ng} / \mathrm{ml}) \mathrm{group}$. Regarding histological type of the patients that tubular adenocarcinoma was $27(73.0 \%)$ in CEA $(<7 \mathrm{ng} / \mathrm{ml})$ group and 10 $(76.9 \%)$ in CEA $(\geq 7 \mathrm{ng} / \mathrm{ml})$ group. Majority patients had tumor size $\leq 5 \mathrm{~cm}$ in both groups, which was $23(62.2 \%)$ in CEA $(<7 \mathrm{ng} / \mathrm{ml})$ group and $07(53.8 \%)$ in CEA $(\geq 7 \mathrm{ng} / \mathrm{ml})$ group. Colon tumor was $16(43.2 \%)$ in CEA $(<7 \mathrm{ng} / \mathrm{ml})$ group and 07 $(53.8 \%)$ in CEA $(\geq 7 \mathrm{ng} / \mathrm{ml})$ group. Peritoneal metastasis was $04(2.7 \%)$ in CEA $(<7 \mathrm{ng} / \mathrm{ml})$ group and $03(23.1 \%)$ in CEA $(\geq 7 \mathrm{ng} / \mathrm{ml})$ group. Liver metastasis was $02(5.4 \%)$ in CEA $(<7 \mathrm{ng} / \mathrm{ml})$ group and $02(15.4 \%)$ in CEA $(\geq 7 \mathrm{ng} / \mathrm{ml})$ group. Regarding TNM staging of the patients CEA $(<7 \mathrm{ng} / \mathrm{ml})$ group majority $19(51.4 \%)$ patients had TNM stage II and CEA $(\geq 7$ $\mathrm{ng} / \mathrm{ml})$ group $07(53.8 \%)$ patients had TNM stage III. Majority patients had moderate histological differentiation in both groups, which was $31(83.8 \%)$ in CEA $(<7 \mathrm{ng} / \mathrm{ml})$ group and $10(76.9 \%)$ in CEA $(\geq 7 \mathrm{ng} / \mathrm{ml})$ group. Mean age was found $43.7 \pm 10.5$ years in CA 19-9 $(<37 \mathrm{ng} / \mathrm{ml})$ group and $41.9 \pm 11.1$ years in CA 19-9 $(\geq 37 \mathrm{ng} / \mathrm{ml})$ group. Colon tumor was 17 $(42.5 \%)$ in CA 19-9 $(<37 \mathrm{ng} / \mathrm{ml})$ group and $06(60.0 \%)$ in CA 19-9 $(\geq 37 \mathrm{ng} / \mathrm{ml})$ group. Peritoneal metastasis was $02(5.0 \%)$ in CA 19-9 $(<37 \mathrm{ng} / \mathrm{ml})$ group and $02(20.0 \%)$ in CA 19-9 $(\geq 37 \mathrm{ng} / \mathrm{ml})$ group. Liver metastasis was $03(7.5 \%)$ in CA 19-9 $(<37 \mathrm{ng} / \mathrm{ml})$ group and $01(10.0 \%)$ in CA 19-9 ( $\geq 37 \mathrm{ng} / \mathrm{ml})$ group. CA $19-9(<37 \mathrm{ng} / \mathrm{ml})$ group majority $19(47.5 \%)$ patients had TNM stage II and CA $19-9(\geq 37 \mathrm{ng} / \mathrm{ml})$ group $06(60.0 \%)$ patients had TNM stage III. Almost two third (62.5\%) patients was found tubular adenocarcinoma in CA $19-9(<37 \mathrm{ng} / \mathrm{ml})$ group and $03(30.0 \%)$ in CA 19-9 ( $\geq 37 \mathrm{ng} / \mathrm{ml})$ group. Majority patients had moderate histological differentiation in both groups, which was $32(80.0 \%)$ in CA $19-9(<37 \mathrm{ng} / \mathrm{ml})$ group and $09(90.0 \%)$ in CA $19-9(\geq 37 \mathrm{ng} / \mathrm{ml})$ group. More than three fourth $(78.0 \%)$ patients had $18.5-24.0 \mathrm{~kg} / \mathrm{m}^{2}, 9$ $(18.0 \%) \mathrm{had}>24.0 \mathrm{~kg} / \mathrm{m}^{2}$ and $2(4.0 \%) \mathrm{had}<18.5 \mathrm{~kg} / \mathrm{m}^{2}$. Cut-off values and prognostic significance of CEA and CA19-9. A higher BMI was shown to be significantly associated with higher plasma volumes. Compared with the normal weight patients, the patients with $\mathrm{BMI} \geq 24$ had $10-15 \%$ higher plasma volumes. The association of BMI with CEA and CA19-9 mass was then investigated. The CEA and CA19-9 mass did not change significantly with increasing BMI, except for CEA in stage. The proportion of patients with overall abnormal CEA and CA19-9 levels at each cut-off value was decreased with BMI. CEA evaluation for colorectal cancer, true positive 3 cases, false positive 10 cases, false negative 8 cases and true negative 29 cases in identification by BMI. Sensitivity of BMI vs CEA was $27.3 \%$, specificity $74.4 \%$, accuracy $64.0 \%$, positive and negative predictive values were $23.1 \%$ and $78.4 \%$ respectively. Sensitivity of BMI vs CA $19-9$ was $27.3 \%$, specificity $82.1 \%$, accuracy $70.0 \%$, positive and negative predictive values were $30.0 \%$ and $80.0 \%$ respectively. Negative correlation ( $r=-0.230 ; \mathrm{p}=0.108)$ between BMI and CEA of colorectal cancer. Conclusion: Inverse correlation was found between body mass index with CEA and CA -19-9 in colorectal cancer patient, but sensitivity and specificity was low. The combination of preoperative CEA and CA19-9 levels was useful for predicting prognosis in patients with colorectal cancer.

Keywords: BMI, CEA of colorectal cancer, CEA and CA19-9, Body Mass Index.

Copyright @ 2020: This is an open-access article distributed under the terms of the Creative Commons Attribution license which permits unrestricted use, distribution, and reproduction in any medium for non-commercial use (NonCommercial, or CC-BY-NC) provided the original author and source are credited. 


\section{INTRODUCTION}

Tumour markers have been commonly employed for several decades in routine clinical settings, including diagnosis, predicting prognosis, and monitoring the effects of treatment. Following the initial description and characterization in 1965 by Gold and Freedman, carcinoembryonic antigen (CEA) has been one of the most extensively investigated markers for colorectal cancer [1]. Serial measurement of serum CEA facilitates the detection of recurrent disease with a sensitivity of $80 \%$ and specificity of $70 \%$, providing a lead time of five months [2]. Carbohydrate antigen 19-9 (CA19-9) and carcinoembryonic antigen (CEA) have been well recognized as tumor markers for colorectal cancer [1]. Numerous studies have demonstrated that colorectal cancer patients with elevated levels of CEA and CA19-9 have a significantly poorer prognosis compared with those with normal levels of these tumor markers [3, 4]. Serial CEA measurements may detect recurrent colorectal cancer with a sensitivity of $80 \%$ and a specificity of $70 \%$ and may provide a lead time of 5 months. CA19-9 has been reported to exhibit a sensitivity of $70-80 \%$ and a specificity of $80-90 \%$ [5]. Elevated preoperative CEA values are associated with more advanced disease and worse outcome following surgical resection, regardless of the tumor stage and histological grade [6-8]. Despite the widespread use of monitoring serum CEA and CA19-9 levels during follow-up, their accuracy clearly determined. Certain non-malignant conditions, such as ageing, chronic renal failure, hypothyroidism, cigarette smoking, chronic obstructive pulmonary disease and obesity may be associated with alterations in serum CEA levels [9-13]. The serum CA19-9 levels are also frequently elevated in patients with various gastrointestinal malignancies, such as pancreatic, colorectal, gastric and hepatic carcinomas. In addition, the serum CA19-9 levels may be elevated in certain non-malignant conditions [14]. According to previous studies, the serum concentration of soluble tumor markers in obese populations is lower compared with that in non obese subjects $[15,16]$. The larger vascular volume of obese individuals exerts a dilutional effect, a phenomenon known as hemodilution. Therefore, the aim of this study is to investigate the association of plasma volume with CEA and CA19-9 concentration in colorectal cancer patients. This study will be conducted to evaluate the association of body mass index (BMI) with serum CEA \& CA19-9 concentration in colorectal cancer patients.

\section{LITERATURE REVIEW History}

The accepted model of colorectral cancer development in that it arises from adenomatous polyps after a sequence of genetic mutations influenced by environmental factors. This adenoma-carcinoma sequence is based on strong observational evidence outlined in below;
1. The prevalence of adenomas and carcinomas is very similar carcinoma patients are about five years older.

2. The distribution of adenomas in the colon in the same as that of cancers (70 percent left sided)

3. When small cancers are studied, they almost always have adjacent adenomatous tissue.

4. Adenomas are found in a third of specimens resected for colorectal cancer.

5. Sporadic adenomas are identical to the adenomas of familial adenomatous polyposis, which is associated with a 100 percent chance of colorectal adenocarcinoma unless treated.

6. Langer adenomas are more likely to be dysplastic and to have higher grades of dysplasia that the small adenomas.

7. Incidence of colorectal cancer falls within a screening programme that involves colonoscopy and polypectomy [17].

\section{Definition}

The majority of colorectal cancers are adenocarcinomas derived from epithelial cells. About $66 \%$ of new colorectal cancers arise in the colon and $38 \%$ in the rectum [18]. Less common types of malignant colorectal tumours are carcinoid tumours, GI stromal cell tumours, and lymphomas. Increasing age is the greatest risk factor for sporadic colorectal adenocarcinoma with $99 \%$ of cancers occurring in people aged 40 years or over.

\section{Incidence}

In Sweden, colorectal cancer is the second most common carcinoma for men after prostate cancer and for women after breast cancer. During 2007, there were 5873 new cases of colorectal cancer in Sweden and rectal cancer accounts for $34 \%$ of these cases (1988 new cases in the year 2007). The incidence of rectal cancer has increased in Sweden between the years 1970 to 2007 (from 15 to 25 new cases per 100000 inhabitants for men and 11 to 18 new cases per 100000 inhabitants for women) (Socialstyrelsens statistikdatabaser).

\section{Signs and Symptoms}

Right sided Tomours: Iron deficiency anaemia, abdominal mass.

Left Sided Tomours: Rectal bleeding, alteration in bowel habit, tenesmus, obstruction.

Metastatic Diseases: Jaundice, aascites, hypatomegaly; other symptoms and signs from rarer sites of metastasis.

There may be considerable overlap between these symptoms [19]. 


\section{Preoperative Investigation}

The aim of the preoperative investigation is to collect sufficient information about the patient and the tumour to offer an individualized treatment. If possible, a colonoscopy is performed to detect synchronous tumours in the colon.

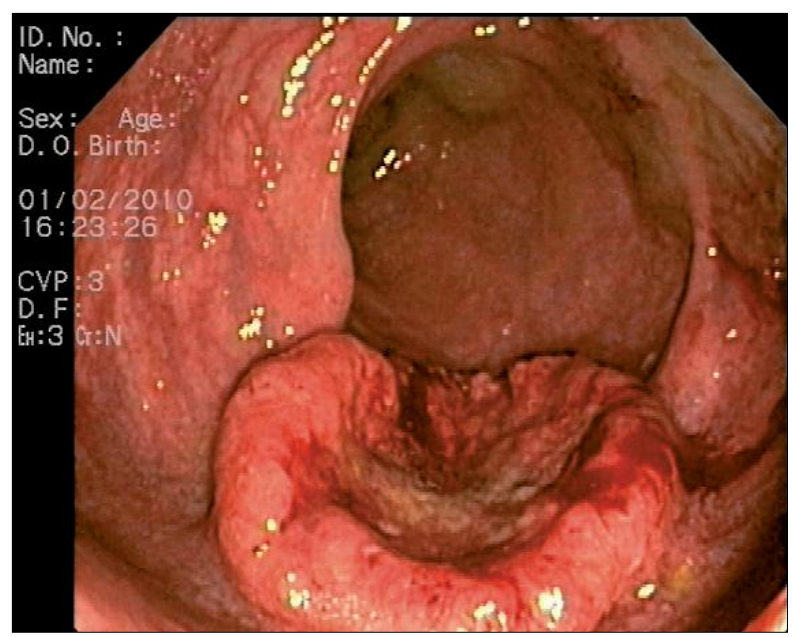

A CT of the abdomen and thorax is performed to detect distant metastases and a MRI of the rectum or rectal US is performed to stage the cancer locally. Both rectal US and MRI can predict T stage with acceptable sensitivity (77-92\%) and specificity (50-74\%), but both modalities have difficulties in predicting $\mathrm{N}$ stage. Lymph nodes are judged according to shape and signal, there is, however, a low correlation between lymph node size and risk of tumour growth [20].

\section{Surgical Treatment}

1. Principles of management of colorectal cancer;

2. Assessment of local and distant tumour spread should be performed both preoperatively and intraoperatively to allow planning of surgery.

3. Synchronous tumours occur in about $5 \%$ of patients and should be excluded preoperatively.

4. Operations are planned to remove the primary tumour and its draining locoregional lymph nodes.

5. Histological examination of resected tumours contributes to decision making regarding the need for adjuvant therapy [19].

Fig-1: Endoscopic view of a rectal cancer

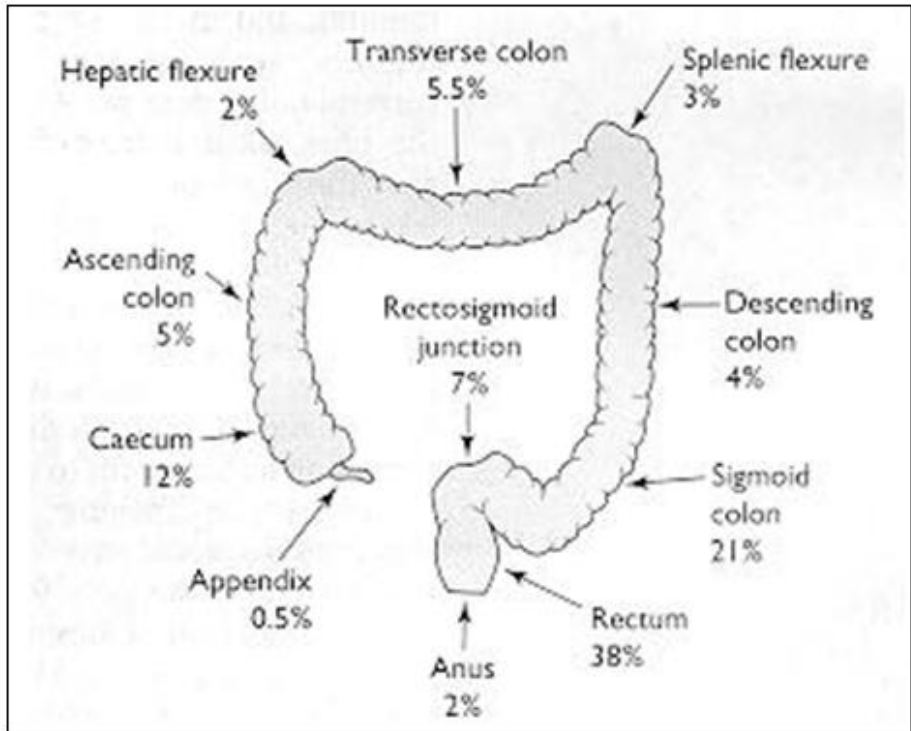

Fig-2: Distribution of the colorectal cancer by site (After Cancer Research Campaign, 1993)

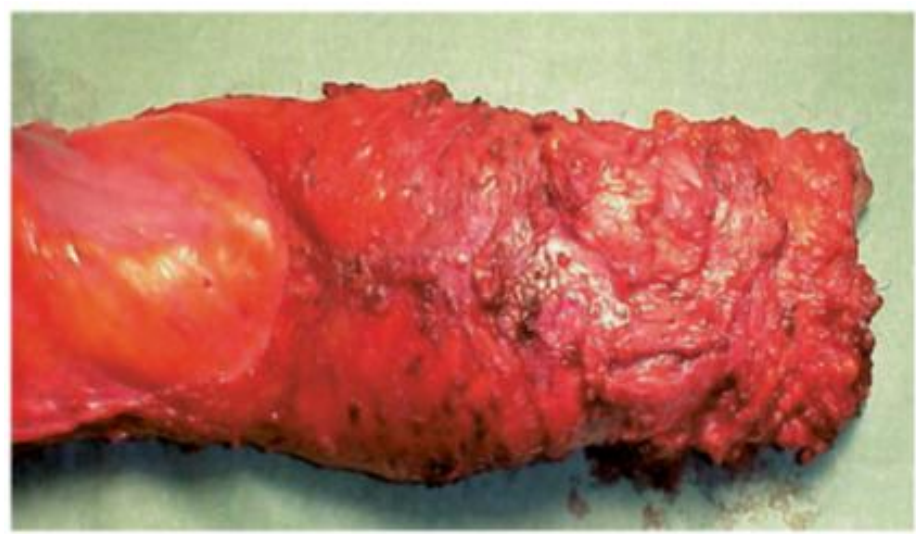

Fig-3: Cylindrical specimen after APR 
With the TME technique, often in combination with radiotherapy, local recurrence rates after an anterior resection have been significantly reduced, but remain unacceptably high for patients with a low rectal cancer operated with an APR.

Histopathological staging:

\section{Colon Cancer - Stages}

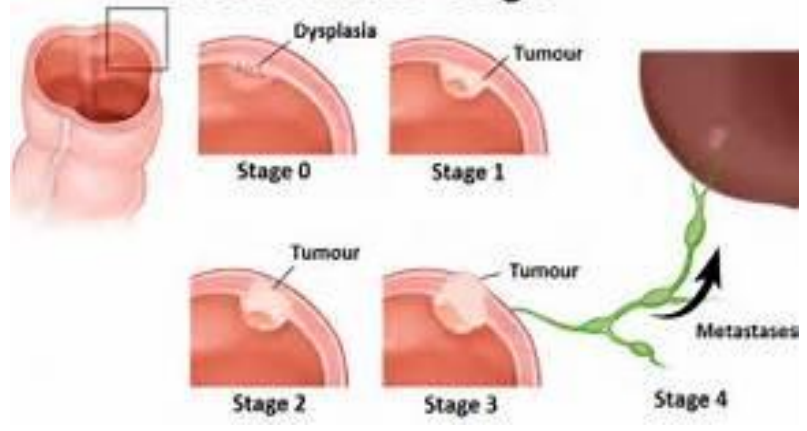

Fig-4: Stage of colon cancer

\section{OBJECTIVES}

General Objective

1. To assess the relation between CEA \& CA 19-

9 level and body mass index in colorectal carcinoma

\section{Specific Objectives}

1. To assess interrelation of CEA, CA 19-9 level and body mass index in colorectal carcinoma

2. To assess how obesity hampers the diagnosis and prognosis of colorectal carcinoma.

Utilization of results: The results of this study may help to increase the confidence among the general and colorectal surgeons about the interrelation between CEA and CA 19-9 level and obesity in colorectal carcinoma.

\section{Methods and Materials \\ Study Design: Prospective Observational Study}

Place of Study: Department of Surgery, Dhaka Medical College Hospital (DMCH).

Study Period: January, 2016 to December, 2016 (12 months)

Study Population: All patients with history, signsymptoms and clinical examination suggesting colorectal carcinoma attended in Dhaka Medical College Hospital for treatment.

Sampling Technique: Purposive sampling (nonrandomized) according to availability of the patients and strictly considering the inclusion and exclusion criteria.

\section{Inclusion Criteria}

1. Patients of colorectal carcinoma with $\mathrm{BMI}>16$ $\mathrm{kg} / \mathrm{m}^{2}$

\section{Exclusion Criteria}

1. The exclusion criteria were as follows:

2. Patients with unregistered data on BMI, CEA and CA19-9,

3. Inflammatory bowel disease,

4. Renal insufficiency requiring hemodialysis,

5. Advanced stage of liver cirrhosis,

6. Cancer of mucinous or sqamous histology,

7. Familial adenomatous polyposis,

8. Synchronous colon cancer.

Sample size: 50

Sample size was calculated by using following statistics

$$
\mathrm{n}=\frac{\mathrm{z}^{2} \mathrm{PQ}}{\mathrm{d}^{2}}
$$

Here, $\mathrm{Z}$ is the confidence limit, $\mathrm{P}$ is the prevalence rate and $\mathrm{Q}$ is 1-P (or, proportion of persons not suffering from the disease), $\mathrm{d}$ is the acceptable standard error and $\mathrm{n}$ is the required sample size.

$$
\begin{aligned}
& \mathrm{Z}=1.96, \mathrm{P}=0.5, \mathrm{Q}=0.5, \mathrm{~d}=0.05 \\
& \text { So, } \mathrm{n}=\left\{(1.96)^{2} \times 0.5 \times 0.5\right\} / 0.05^{2}
\end{aligned}
$$

\section{Investigation Variables}

1. Pre-operative CEA level

2. Pre-operative CA-19-9

\section{Study Procedure}

Data was collected with a pre-tested structured questionnaire containing history, clinical examination, laboratory investigations, pre-operative, per-operative, postoperative follow up findings. This study was conducted to evaluate the association between CEA, CA 19-9 and body mass index in colorectal cancer patients. A total of 50 patients of colorectal cancer who were undergone surgical treatment were enrolled in the study, between January, 2016 and December, 2016. Height and weight was objectively measured at admission and preoperative BMI was calculated as weight in kilograms divided by height in meters square. In view of the differences in the recommended BMI cut-off points for overweight status and obesity, the following categories was used: lower range of normal weight (BMI $<18.5 \mathrm{~kg} / \mathrm{m}^{2}$ ), normal weight $\left(\mathrm{BMI}=18.5-24.0 \mathrm{~kg} / \mathrm{m}^{2}\right.$ ) and overweight (BMI $>24.0$ $\mathrm{kg} / \mathrm{m}^{2}$ ). The baseline serum CEA and CA19-9 concentrations were measured by enzyme immunoassay in a single laboratory at Bangabandhu Sheikh Mujib Medical University, Dhaka. The estimated body surface area was calculated as follows: (body weight) $\mathbf{0 . 4 2 5} \mathrm{x}$ (height) $0.72 \times 0.007184$. The CEA and CA19-9 mass (in micrograms), representing the total amount of CEA and CA19-9 protein within the circulation was calculated as serum CEA and CA19-9 concentration X estimated plasma volume. The estimated plasma 
volume (in liters) was calculated by $5 \%$ of the total body weight. The follow up examinations was included physical examination, serum carcinoembryonic antigen levels, chest X-rays, abdominal ultrasonography, or thoracoabdominal computed tomography performed at 3 month intervals. The association of BMI with CEA \& CA-19-9 concentration, total circulating CEA \& CA19-9 level and plasma volume was assessed by determining P-values for trends. Correlation and regression analyses were performed to calculate the values and formulas to evaluate the association between clinical parameters and log-transformed serum levels. Multiple linear regression analyses were performed to assess whether clinical parameters significantly contributed to interpreting serum CEA and CA19-9 levels. Only the variables that was statistically significant $(\mathrm{P}<0.05)$ in the Pearson's linear regression analysis was included in the multiple linear regression model. A stepwise method was used to select the explanatory variables based on analysis of variance.

\section{Follow up of the patient}

The patients were followed up at 3 month. The follow-up examinations were included history, physical examination, BMI, serum carcinoembryonic antigen levels, CA 19-9, X-rays chest P/A view, abdominal ultrasonography, or thoracoabdominal computed tomography performed at each schedule.

\section{Data Collection Procedure}

Data was collected with a pre-tested structured questionnaire containing history, clinical, laboratory investigations, pre-operative, per-operative findings and complications.

\section{Data Analysis}

Statistical analyses were carried out by using the Statistical Package for Social Sciences version 17.0 for Windows (SPSS Inc., Chicago, Illinois, USA). The mean values were calculated for continuous variables. The quantitative observations were indicated by frequencies and percentages. Chi-Square test was used to analyze the categorical variables, shown with cross tabulation. Student t-test was used for continuous variables. ANOVA test was used to analyze the continuous variables, shown with mean and standard deviation. $\mathrm{P}$ values $<0.05$ was considered as statistically significant.

\section{Ethical Consideration}

Informed written consent was taken from the patient or patient's guardian after duly informing the procedure of treatment, anticipated result, possible advantages, disadvantages and complications considering all ethical issues. Confidentiality was maintained both verbally and documentary by using separate locker and computer pass ward.

\section{RESULTS}

Total 50 cases majority patients belonged to age 41-50 years in both groups (CEA $<7 \mathrm{ng} / \mathrm{ml}$ and $\geq 7$ $\mathrm{ng} / \mathrm{ml})$. The mean age was found $42.5 \pm 11.3$ years in CEA $(<7 \mathrm{ng} / \mathrm{ml})$ group and $40.7 \pm 12.1$ years in CEA $(\geq 7$ $\mathrm{ng} / \mathrm{ml})$ group. Male was found $15(40.5 \%)$ in CEA $(<7$ $\mathrm{ng} / \mathrm{ml})$ group and $06(46.2 \%)$ in CEA ( $\geq 7 \mathrm{ng} / \mathrm{ml})$ group. Regarding histological type of the patients that tubular adenocarcinoma was $27(73.0 \%)$ in CEA $(<7 \mathrm{ng} / \mathrm{ml})$ group and $10(76.9 \%)$ in CEA $(\geq 7 \mathrm{ng} / \mathrm{ml})$ group.

Table-1: Association between CEA with age $(\mathbf{n}=50)$

\begin{tabular}{|c|c|c|c|c|c|}
\hline \multirow[t]{2}{*}{ Age (years) } & \multicolumn{2}{|c|}{$\begin{array}{l}\text { CEA }(<7 \mathrm{ng} / \mathrm{ml}) \\
(\mathrm{n}=37)\end{array}$} & \multicolumn{2}{|c|}{$\begin{array}{l}\operatorname{CEA}(\geq 7 \mathrm{ng} / \mathrm{ml}) \\
(\mathrm{n}=13)\end{array}$} & \multirow[t]{2}{*}{ P value } \\
\hline & $\mathbf{n}$ & $\%$ & $\mathbf{n}$ & $\%$ & \\
\hline$\leq 30$ & 05 & 13.5 & 02 & 15.4 & \\
\hline $31-40$ & 09 & 24.3 & 04 & 30.8 & \\
\hline $41-50$ & 13 & 35.1 & 05 & 38.5 & \\
\hline $51-60$ & 10 & 27.0 & 02 & 15.4 & \\
\hline Mean \pm SD & \multicolumn{2}{|c|}{$42.5 \pm 11.3$} & \multicolumn{2}{|c|}{$40.7 \pm 12.1$} & $0.629^{\mathrm{ns}}$ \\
\hline
\end{tabular}

Table-1 shows age distribution of the patients. It was observed that majority patients belonged to age 41-50 years in both groups (CEA $<7 \mathrm{ng} / \mathrm{ml}$ and CEA $\geq$ $7 \mathrm{ng} / \mathrm{ml}$ group). The mean age was found $42.5 \pm 11.3$ years in CEA $(<7 \mathrm{ng} / \mathrm{ml})$ group and $40.7 \pm 12.1$ years in CEA $(\geq 7 \mathrm{ng} / \mathrm{ml})$ group. The mean difference was not statistically significant $(p>0.05)$ between the groups. 


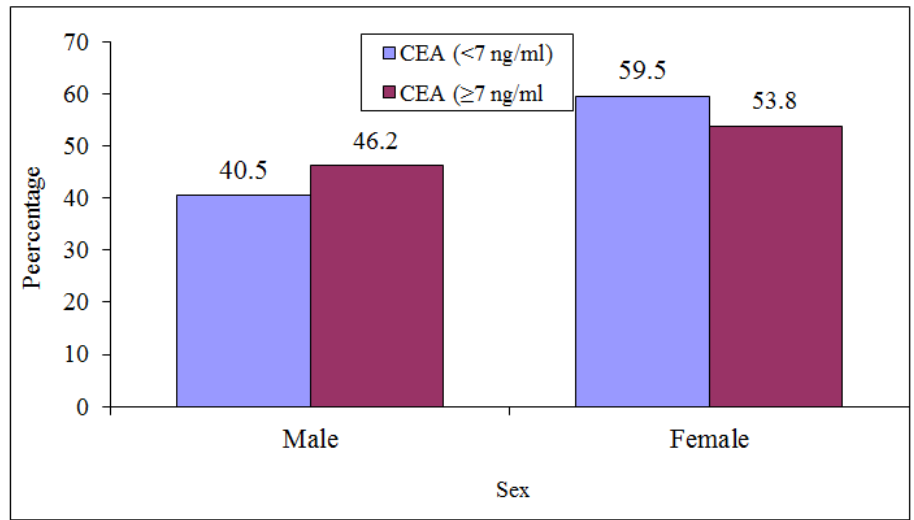

Fig-5: Bar diagram shows association between CEA with sex of the study patients $\mathbf{p}=\mathbf{0 . 7 4 2}$

$\mathrm{P}$ value reached from Chi square test

Regarding sex distribution of the patients. It was observed that male was found $15(40.5 \%)$ in CEA $(<7 \mathrm{ng} / \mathrm{ml})$ group and $06(46.2 \%)$ in CEA $(\geq 7 \mathrm{ng} / \mathrm{ml})$ group. Male female difference was not statistically significant $(\mathrm{p}>0.05)$ between the groups (Figure-5).

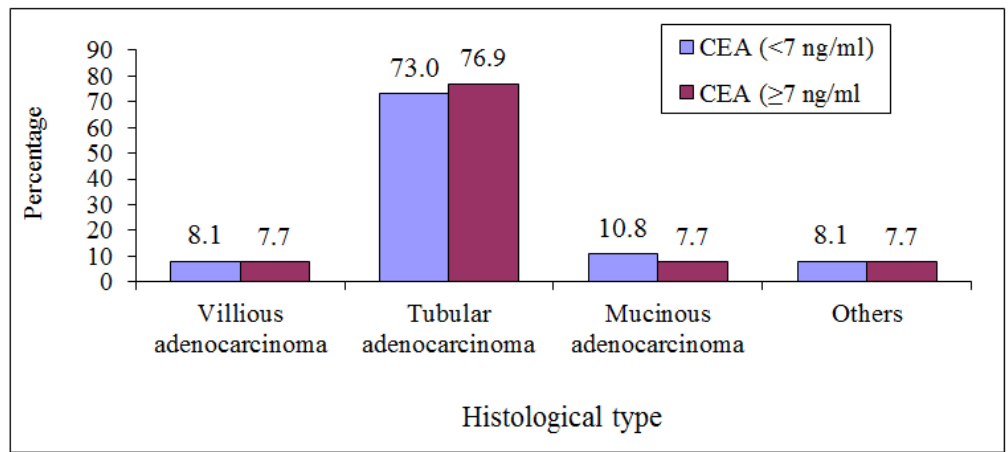

Fig-6: Bar diagram shows association between CEA with histological type of the study patients $\mathbf{p}=0.989$ $P$ value reached from Chi square test

Regarding histological type of the patients. It was observed that tubular adenocarcinoma was 27 $(73.0 \%)$ in CEA $(<7 \mathrm{ng} / \mathrm{ml})$ group and $10(76.9 \%)$ in
CEA ( $\geq 7 \mathrm{ng} / \mathrm{ml})$ group. The difference was not statistically significant $(\mathrm{p}>0.05)$ between the groups [Figure-6].

Table-2: Association between CEA with tumor size $(\mathbf{n}=50)$

\begin{tabular}{|c|c|c|c|c|c|}
\hline \multirow[t]{2}{*}{ Tumor size (cm) } & \multicolumn{2}{|c|}{$\begin{array}{l}\text { CEA (<7 ng/ml) } \\
(n=37)\end{array}$} & \multicolumn{2}{|c|}{$\begin{array}{l}\text { CEA }(\geq 7 \mathrm{ng} / \mathrm{ml}) \\
(\mathrm{n}=13)\end{array}$} & \multirow[t]{2}{*}{ P value } \\
\hline & n & $\%$ & $\mathbf{n}$ & $\%$ & \\
\hline$\leq 5$ & 23 & 62.2 & 07 & 53.8 & \multirow[t]{2}{*}{$0.456^{\mathrm{ns}}$} \\
\hline$>5$ & 14 & 37.8 & 06 & 46.2 & \\
\hline
\end{tabular}

Table-2 shows tumor size of the patients. It was observed that majority patients had tumor size $\leq 5$ $\mathrm{cm}$ in both groups, which was $23(62.2 \%)$ in CEA $(<7$ $\mathrm{ng} / \mathrm{ml})$ group and $07(53.8 \%)$ in CEA $(\geq 7 \mathrm{ng} / \mathrm{ml})$ group. The difference was not statistically significant $(\mathrm{p}>0.05)$ between the groups.

Table-3: Association between CEA with tumor location $(\mathbf{n}=50)$

\begin{tabular}{|c|c|c|c|c|c|}
\hline \multirow[t]{2}{*}{ Tumor location } & \multicolumn{2}{|c|}{$\begin{array}{l}\text { CEA }(<7 \mathrm{ng} / \mathrm{ml}) \\
(\mathrm{n}=37)\end{array}$} & \multicolumn{2}{|c|}{$\begin{array}{l}\text { CEA }(\geq 7 \mathrm{ng} / \mathrm{ml}) \\
(\mathrm{n}=13)\end{array}$} & \multirow[t]{2}{*}{$P$ value } \\
\hline & n & $\%$ & n & $\%$ & \\
\hline Colon & 16 & 43.2 & 07 & 53.8 & \multirow[t]{2}{*}{$0.509^{\mathrm{ns}}$} \\
\hline Rectum & 21 & 56.8 & 06 & 46.2 & \\
\hline
\end{tabular}


Table-3 shows tumor location of the patients. It was observed that colon tumor was $16(43.2 \%)$ in CEA $(<7 \mathrm{ng} / \mathrm{ml})$ group and $07(53.8 \%)$ in CEA $(\geq 7$ $\mathrm{ng} / \mathrm{ml}$ ) group. The difference was not statistically significant $(\mathrm{p}>0.05)$ between the groups.

Table-4: Association between CEA with peritoneal metastasis $(\mathbf{n}=50)$

\begin{tabular}{|c|c|c|c|c|c|}
\hline \multirow[t]{2}{*}{ Peritoneal metastasis } & \multicolumn{2}{|c|}{$\begin{array}{l}\text { CEA }(<7 \mathrm{ng} / \mathrm{ml}) \\
(\mathrm{n}=37)\end{array}$} & \multicolumn{2}{|c|}{$\begin{array}{l}\text { CEA }(\geq 7 \mathrm{ng} / \mathrm{ml}) \\
(\mathrm{n}=13)\end{array}$} & \multirow[t]{2}{*}{$P$ value } \\
\hline & $\mathbf{n}$ & $\%$ & n & $\%$ & \\
\hline No & 36 & 97.3 & 10 & 76.9 & \multirow[t]{2}{*}{$0.019^{\mathrm{s}}$} \\
\hline Yes & 01 & 2.7 & 03 & 23.1 & \\
\hline
\end{tabular}

$\mathrm{P}$ value reached from Chi square test

Table-4 shows peritoneal metastasis of the patients. It was observed that peritoneal metastasis was $04(2.7 \%)$ in CEA $(<7 \mathrm{ng} / \mathrm{ml})$ group and $03(23.1 \%)$ in
CEA ( $\geq 7 \mathrm{ng} / \mathrm{ml})$ group. The difference was statistically significant $(\mathrm{p}<0.05)$ between the groups.

Table-5: Association between CEA with liver metastasis $(\mathbf{n}=50)$

\begin{tabular}{|l|l|l|l|l|l|}
\hline \multirow{2}{*}{ Liver metastasis } & \multicolumn{2}{l}{$\begin{array}{l}\text { CEA (<7 ng/ml) } \\
(\mathbf{n = 3 7 )}\end{array}$} & \multicolumn{2}{l|}{$\begin{array}{l}\text { CEA ( }(\mathbf{7} \mathbf{n g} / \mathbf{m l}) \\
(\mathbf{n = 1 3})\end{array}$} & \multirow{2}{*}{ P value } \\
\cline { 2 - 5 } & $\mathbf{n}$ & $\mathbf{\%}$ & $\mathbf{n}$ & $\mathbf{\%}$ & \\
\hline No & 35 & 94.6 & 11 & 84.6 & \multirow{2}{*}{$0.253^{\text {ns }}$} \\
\hline Yes & 02 & 5.4 & 02 & 15.4 & \\
\hline \multicolumn{6}{c}{ ns=not significant } \\
\hline
\end{tabular}

Table- 5 shows liver metastasis of the patients. It was observed that liver metastasis was $02(5.4 \%)$ in CEA $(<7 \mathrm{ng} / \mathrm{ml})$ group and $02(15.4 \%)$ in CEA $(\geq 7$ $\mathrm{ng} / \mathrm{ml}$ ) group. The difference was not statistically significant $(p>0.05)$ between the groups.

Table-6: Association between CEA with TNM stage (n=50)

\begin{tabular}{|c|c|c|c|c|c|}
\hline \multirow[t]{2}{*}{ TNM stage } & \multicolumn{2}{|c|}{$\begin{array}{l}\text { CEA (<7 ng/ml) } \\
(\mathrm{n}=37)\end{array}$} & \multicolumn{2}{|c|}{$\begin{array}{l}\text { CEA }(\geq 7 \mathrm{ng} / \mathrm{ml}) \\
(\mathrm{n}=13)\end{array}$} & \multirow[t]{2}{*}{$P$ value } \\
\hline & n & $\%$ & n & $\%$ & \\
\hline $\mathrm{I}$ & 08 & 21.6 & 01 & 7.7 & \multirow[t]{4}{*}{$0.015^{\mathrm{s}}$} \\
\hline II & 19 & 51.4 & 02 & 15.4 & \\
\hline III & 08 & 21.6 & 07 & 53.8 & \\
\hline IV & 02 & 5.4 & 03 & 23.1 & \\
\hline
\end{tabular}

Regarding TNM staging of the patients. It was observed that in CEA $(<7 \mathrm{ng} / \mathrm{ml})$ group majority 19 $(51.4 \%)$ patients had TNM stage II and CEA ( $\geq 7 \mathrm{ng} / \mathrm{ml})$ group $07(53.8 \%)$ patients had TNM stage III. The difference was statistically significant $(\mathrm{p}<0.05)$ between the groups (Table-6).

Table-7: Association between CEA with histological differentiation $(n=50)$

\begin{tabular}{|c|c|c|c|c|c|}
\hline \multirow[t]{2}{*}{ Histological differentiation } & \multicolumn{2}{|c|}{$\begin{array}{l}\text { CEA }(<7 \mathrm{ng} / \mathrm{ml}) \\
(\mathrm{n}=37)\end{array}$} & \multicolumn{2}{|c|}{$\begin{array}{l}\text { CEA }(\geq 7 \mathrm{ng} / \mathrm{ml}) \\
(\mathrm{n}=13)\end{array}$} & \multirow[t]{2}{*}{ P value } \\
\hline & $\mathbf{n}$ & $\%$ & $\mathbf{n}$ & $\%$ & \\
\hline High & 03 & 8.1 & 01 & 7.7 & \multirow[t]{3}{*}{$0.753^{\mathrm{ns}}$} \\
\hline Moderate & 31 & 83.8 & 10 & 76.9 & \\
\hline Poor & 03 & 8.1 & 02 & 15.4 & \\
\hline
\end{tabular}

Table-7 shows histological differentiation of the patients. It was observed that majority patients had moderate histological differentiation in both groups, which was $31(83.8 \%)$ in CEA $(<7 \mathrm{ng} / \mathrm{ml})$ group and 10 $(76.9 \%)$ in CEA ( $\geq 7 \mathrm{ng} / \mathrm{ml})$ group. The difference was not statistically significant $(\mathrm{p}>0.05)$ between the groups. 
Table-8: Association between CA 19-9 with age $(\mathbf{n}=50)$

\begin{tabular}{|l|l|l|l|l|l|}
\hline \multirow{2}{*}{ Age (years) } & \multicolumn{2}{l|}{$\begin{array}{l}\text { CA 19-9 }(<37 \mathbf{n g} / \mathbf{m l}) \\
(\mathbf{n = 4 0})\end{array}$} & \multicolumn{2}{l}{$\begin{array}{l}\text { CA 19-9 }(\geq 37 \mathbf{~ n g} / \mathbf{m l}) \\
(\mathbf{n = 1 0})\end{array}$} & \multirow{2}{*}{ P value } \\
\cline { 2 - 5 } & $\mathbf{n}$ & $\mathbf{\%}$ & $\mathbf{n}$ & $\mathbf{\%}$ & \\
\hline$\leq 30$ & 06 & 15.0 & 01 & 10.0 & \\
\hline $31-40$ & 08 & 20.0 & 05 & 50.0 & \\
\hline $41-50$ & 15 & 37.5 & 03 & 30.0 & \\
\hline $51-60$ & 11 & 27.5 & 01 & 10.0 & \\
\hline Mean \pm SD & $43.7 \pm 10.5$ & $41.9 \pm 11.1$ & & $0.633^{\mathrm{ns}}$ \\
\hline
\end{tabular}

ns=not significant

$P$ value reached from unpaired t-test

Table- 8 shows age distribution of the patients. It was observed that mean age was found $43.7 \pm 10.5$ years in CA 19-9 (<37 ng/ml) group and 41.9 \pm 11.1 years in CA 19-9 $(\geq 37 \mathrm{ng} / \mathrm{ml})$ group. The mean difference was not statistically significant $(p>0.05)$ between the groups.

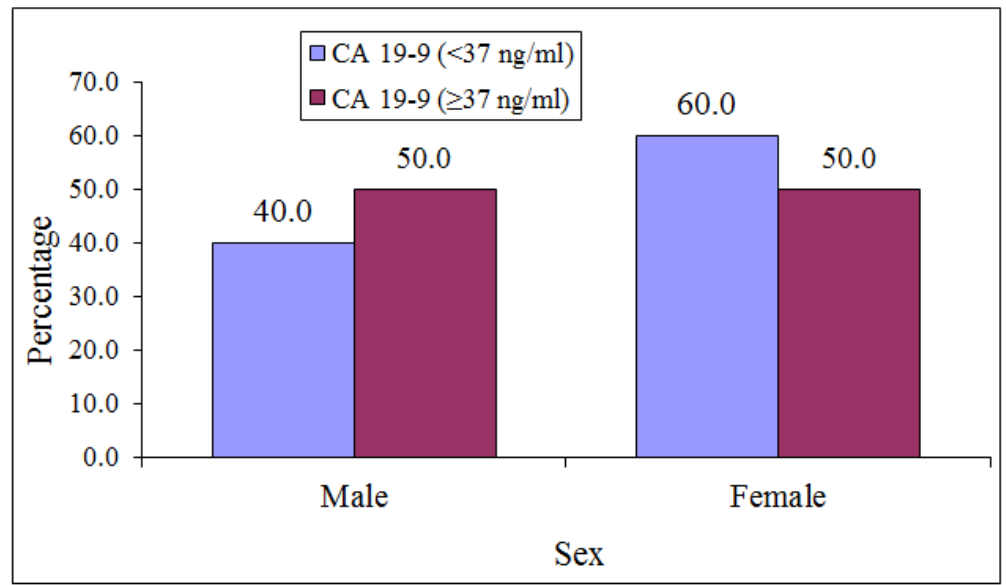

Fig-7: Bar diagram shows association between CA 19-9 with sex of the study patients $\mathrm{p}=0.566, \mathrm{P}$ value reached from Chi square test

Regarding sex distribution of the patients. It was observed that male was found $16(40.0 \%)$ in CA $19-9(<7 \mathrm{ng} / \mathrm{ml})$ group and $05(50.0 \%)$ in CA 19-9 $(\geq 37$ ng/ml) group. Male female difference was not statistically significant $(\mathrm{p}>0.05)$ between the groups (Figure-7).

Table-9: Association between CA 19-9 with tumor size $(n=50)$

\begin{tabular}{|c|c|c|c|c|c|}
\hline \multirow[t]{2}{*}{ Tumor size } & \multicolumn{2}{|c|}{$\begin{array}{l}\text { CA 19-9 }(<37 \mathrm{ng} / \mathrm{ml}) \\
(n=40)\end{array}$} & \multicolumn{2}{|c|}{$\begin{array}{l}\text { CA 19-9 }(\geq 37 \mathrm{ng} / \mathrm{ml}) \\
(\mathrm{n}=10)\end{array}$} & \multirow[t]{2}{*}{$P$ value } \\
\hline & $\mathbf{n}$ & $\%$ & $\mathbf{n}$ & $\%$ & \\
\hline$\leq 5$ & 25 & 62.5 & 05 & 50.0 & \multirow[t]{2}{*}{$0.470^{\mathrm{ns}}$} \\
\hline$>5$ & 15 & 37.5 & 05 & 50.0 & \\
\hline
\end{tabular}

ns=not significant

$\mathrm{P}$ value reached from Chi square test

Table-9 shows tumor size of the patients. It was observed that majority patients had tumor size $\leq 5$ $\mathrm{cm}$ in both groups, which was $25(62.5 \%)$ in CA $19-9$
$(<37 \mathrm{ng} / \mathrm{ml})$ group and $05(50.0 \%)$ in CA $19-9(\geq 37$ $\mathrm{ng} / \mathrm{ml})$ group. The difference was not statistically significant $(\mathrm{p}>0.05)$ between the groups.

Table-10: Association between CA 19-9 with tumor location $(n=50)$

\begin{tabular}{|c|c|c|c|c|c|}
\hline \multirow[t]{2}{*}{ Tumor location } & \multicolumn{2}{|c|}{$\begin{array}{l}\text { CA 19-9 }(<37 \mathrm{ng} / \mathrm{ml}) \\
(\mathrm{n}=40)\end{array}$} & \multicolumn{2}{|c|}{$\begin{array}{l}\text { CA 19-9 }(\geq 37 \mathrm{ng} / \mathrm{ml}) \\
(\mathrm{n}=10)\end{array}$} & \multirow[t]{2}{*}{ P value } \\
\hline & $\mathbf{n}$ & $\%$ & $\mathbf{n}$ & $\%$ & \\
\hline Colon & 17 & 42.5 & 06 & 60.0 & \multirow[t]{2}{*}{$0.320^{\mathrm{ns}}$} \\
\hline Rectum & 23 & 57.5 & 04 & 40.0 & \\
\hline
\end{tabular}

$\mathrm{P}$ value reached from Chi square test 
Table-10 shows tumor location of the patients. It was observed that colon tumor was $17(42.5 \%)$ in CA $19-9(<37 \mathrm{ng} / \mathrm{ml})$ group and $06(60.0 \%)$ in CA 19-9 $(\geq 37 \mathrm{ng} / \mathrm{ml}$ ) group. The difference was not statistically significant $(\mathrm{p}>0.05)$ between the groups.

Table-11: Association between CA 19-9 with peritoneal metastasis $(n=50)$

\begin{tabular}{|c|c|c|c|c|c|}
\hline \multirow[t]{2}{*}{ Peritoneal metastasis } & \multicolumn{2}{|c|}{$\begin{array}{l}\text { CA } 19-9(<37 \mathrm{ng} / \mathrm{ml}) \\
(\mathrm{n}=40)\end{array}$} & \multicolumn{2}{|c|}{$\begin{array}{l}\text { CA 19-9 }(\geq 37 \mathrm{ng} / \mathrm{ml}) \\
(\mathrm{n}=10)\end{array}$} & \multirow[t]{2}{*}{ P value } \\
\hline & n & $\%$ & $\mathbf{n}$ & $\%$ & \\
\hline No & 38 & 95.0 & 08 & 80.0 & \multirow[t]{2}{*}{$0.117^{\mathrm{ns}}$} \\
\hline Yes & 02 & 5.0 & 02 & 20.0 & \\
\hline
\end{tabular}

Table-11 shows peritoneal metastasis of the patients. It was observed that peritoneal metastasis was $02(5.0 \%)$ in CA $19-9(<37 \mathrm{ng} / \mathrm{ml})$ group and 02
(20.0\%) in CA 19-9 ( $\geq 37 \mathrm{ng} / \mathrm{ml})$ group. The difference was not statistically significant $(\mathrm{p}>0.05)$ between the groups.

Table-12: Association between CA 19-9 with liver metastasis $(n=50)$

\begin{tabular}{|c|c|c|c|c|c|}
\hline \multirow[t]{2}{*}{ Liver metastasis } & \multicolumn{2}{|c|}{$\begin{array}{l}\text { CA 19-9 }(<37 \mathrm{ng} / \mathrm{ml}) \\
(\mathrm{n}=40)\end{array}$} & \multicolumn{2}{|c|}{$\begin{array}{l}\text { CA 19-9 }(\geq 37 \mathrm{ng} / \mathrm{ml}) \\
(\mathrm{n}=10)\end{array}$} & \multirow[t]{2}{*}{$P$ value } \\
\hline & $\mathbf{n}$ & $\%$ & n & $\%$ & \\
\hline No & 37 & 92.5 & 09 & 90.0 & \multirow[t]{2}{*}{$0.794^{\mathrm{ns}}$} \\
\hline Yes & 03 & 7.5 & 01 & 10.0 & \\
\hline
\end{tabular}

$\mathrm{P}$ value reached from Chi square test

Table-12 shows liver metastasis of the patients. It was observed that liver metastasis was $03(7.5 \%)$ in CA 19-9 (<37 ng/ml) group and $01(10.0 \%)$ in CA 19-9
( $\geq 37 \mathrm{ng} / \mathrm{ml}$ ) group. The difference was not statistically significant $(\mathrm{p}>0.05)$ between the groups.

Table-13: Association between CA 19-9 with TNM stage $(\mathbf{n}=50)$

\begin{tabular}{|c|c|c|c|c|c|}
\hline \multirow[t]{2}{*}{ TNM stage } & \multicolumn{2}{|c|}{$\begin{array}{l}\text { CA 19-9 }(<37 \mathrm{ng} / \mathrm{ml}) \\
(\mathrm{n}=40)\end{array}$} & \multicolumn{2}{|c|}{$\begin{array}{l}\text { CA 19-9 }(\geq 37 \mathrm{ng} / \mathrm{ml}) \\
(\mathrm{n}=10)\end{array}$} & \multirow[t]{2}{*}{$P$ value } \\
\hline & $n$ & $\%$ & $\mathbf{n}$ & $\%$ & \\
\hline I & 09 & 22.5 & 00 & 0.0 & \multirow{4}{*}{$0.033^{\mathrm{s}}$} \\
\hline II & 19 & 47.5 & 02 & 20.0 & \\
\hline III & 09 & 22.5 & 06 & 60.0 & \\
\hline IV & 03 & 7.5 & 02 & 20.0 & \\
\hline
\end{tabular}

Regarding TNM staging of the patients. It was observed that in CA $19-9(<37 \mathrm{ng} / \mathrm{ml})$ group majority $19(47.5 \%)$ patients had TNM stage II and CA 19-9
( $\geq 37 \mathrm{ng} / \mathrm{ml}$ ) group $06(60.0 \%)$ patients had TNM stage III. The difference was statistically significant $(\mathrm{p}<0.05)$ between the groups (Table-13)

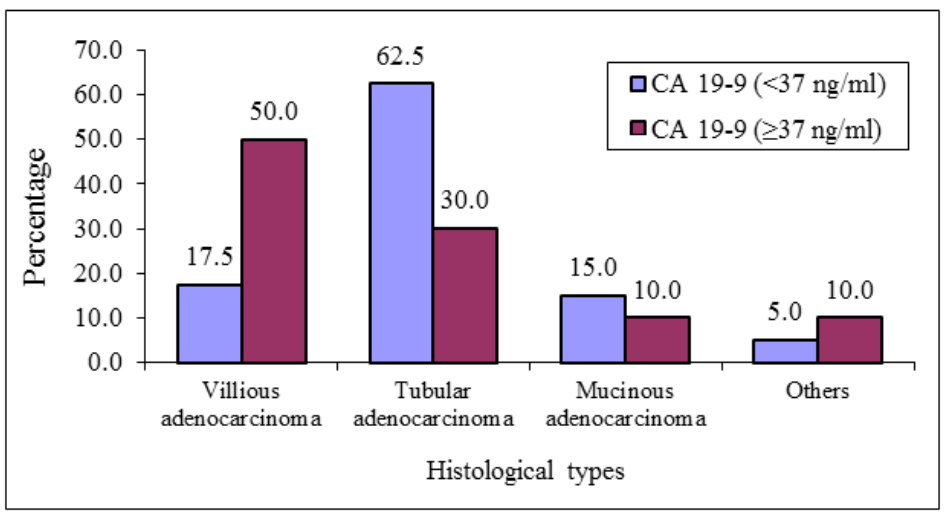

Fig-8: Bar diagram shows association between CA 19-9 with histological types of the study patients $p=0.138$ $\mathrm{P}$ value reached from Chi square test 
Almost two third $(62.5 \%)$ patients was found tubular adenocarcinoma in CA $19-9(<37 \mathrm{ng} / \mathrm{ml})$ group and $03(30.0 \%)$ in CA $19-9(\geq 37 \mathrm{ng} / \mathrm{ml})$ group. The difference was not statistically significant $(p>0.05)$ between the groups (Figure-8).

Table-14: Association between CA 19-9 with histological differentiation $(n=50)$

\begin{tabular}{|c|c|c|c|c|c|}
\hline \multirow[t]{2}{*}{ Histological differentiation } & \multicolumn{2}{|c|}{$\begin{array}{l}\text { CA 19-9 }(<37 \mathrm{ng} / \mathrm{ml}) \\
(\mathrm{n}=40)\end{array}$} & \multicolumn{2}{|c|}{$\begin{array}{l}\text { CA 19-9 }(\geq 37 \mathrm{ng} / \mathrm{ml}) \\
(\mathrm{n}=10)\end{array}$} & \multirow[t]{2}{*}{ P value } \\
\hline & $\mathrm{n}$ & $\%$ & $\mathrm{n}$ & $\%$ & \\
\hline High & 04 & 10.0 & 00 & 0.0 & \multirow{3}{*}{$0.577^{\mathrm{ns}}$} \\
\hline Moderate & 32 & 80.0 & 09 & 90.0 & \\
\hline Poor & 04 & 10.0 & 01 & 10.0 & \\
\hline
\end{tabular}

Table-14 shows histological differentiation of the patients. It was observed that majority patients had moderate histological differentiation in both groups, which was $32(80.0 \%)$ in CA $19-9(<37 \mathrm{ng} / \mathrm{ml})$ group and $09(90.0 \%)$ in CA $19-9(\geq 37 \mathrm{ng} / \mathrm{ml})$ group. The difference was not statistically significant $(p>0.05)$ between the groups.

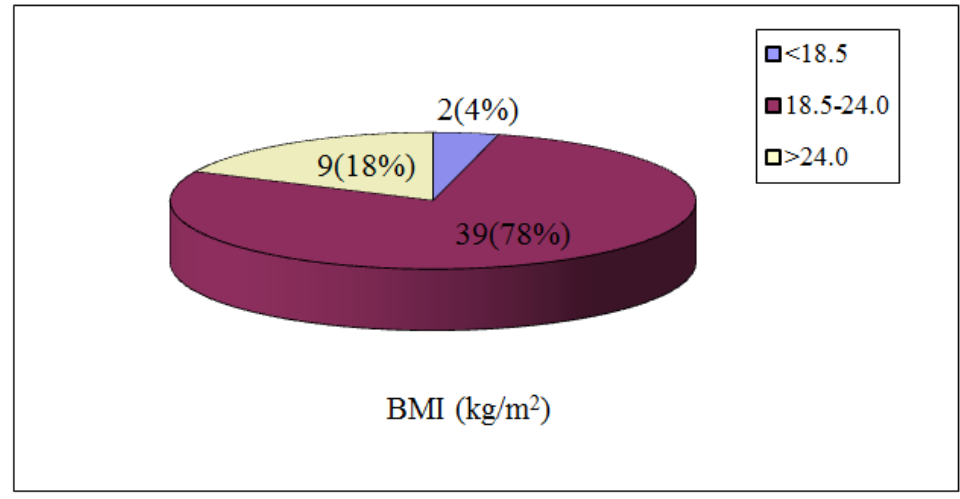

Fig-9: Pie chart shows BMI of the study patients

More than three fourth (78.0\%) patients had $18.5-24.0 \mathrm{~kg} / \mathrm{m}^{2}, 9(18.0 \%)$ had $>24.0 \mathrm{~kg} / \mathrm{m}^{2}$ and $2(4.0 \%) \mathrm{had}$ $<18.5 \mathrm{~kg} / \mathrm{m}^{2}$ (Figure-9).

Table-15: Plasma volume and carcinoembryonic antigen (CEA) and carbohydrate antigen 19-9 (CA 19-9) mass according to body mass index (BMI) category

\begin{tabular}{|c|c|c|c|c|}
\hline \multirow[t]{2}{*}{ Stage } & \multicolumn{3}{|l|}{ BMI category $\left(\mathrm{kg} / \mathrm{m}^{2}\right)$} & \multirow[t]{2}{*}{$\mathrm{P}$ value } \\
\hline & $<18.5$ & $18.5-24.0$ & $>24$ & \\
\hline \multicolumn{5}{|c|}{ Plasma volume, liters (SD) } \\
\hline I & $2.45(0.16)$ & $2.62(0.21)$ & $2.80(0.23)$ & $0.003^{\mathrm{s}}$ \\
\hline II & $2.32(0.24)$ & $2.58(0.25)$ & $2.82(0.28)$ & $0.001^{\mathrm{s}}$ \\
\hline III & $2.44(0.17)$ & $2.50(0.22)$ & $2.77(0.26)$ & $0.001^{\mathrm{s}}$ \\
\hline IV & $2.47(0.15)$ & $2.64(0.19)$ & $2.85(0.36)$ & $0.001^{\mathrm{s}}$ \\
\hline \multicolumn{5}{|c|}{$\begin{array}{l}\text { CEA mass, } \\
\mu \mathrm{g}(\mathrm{IQR})\end{array}$} \\
\hline $\mathrm{I}$ & $4.25(3.17-5.15)$ & $6.47(4.60-10.69)$ & $6.10(3.37-12.25)$ & $0.047^{\mathrm{s}}$ \\
\hline II & $8.11(4.96-13.00)$ & $7.36(4.70-14.84)$ & $12.92(5.00-21.24)$ & $0.549^{\mathrm{ns}}$ \\
\hline III & $13.25(4.62-26.30)$ & $9.65(3.98-19.31)$ & $6.53(3.61-19.80)$ & $0.087^{\mathrm{ns}}$ \\
\hline IV & $21.60(6.65-49.96)$ & $30.26(9.12-76.14)$ & $35.29(10.64-98.27)$ & $0.419^{\mathrm{ns}}$ \\
\hline \multicolumn{5}{|c|}{ CA 19-9 mass, $\mu \mathrm{g}$ (IQR) } \\
\hline I & $36.61(26.96-57.34)$ & $42.71(27.92-59.98)$ & 70.55 (37.49-103.27) & $0.827^{\mathrm{ns}}$ \\
\hline II & $62.25(26.74-69.86)$ & $51.29(29.21-79.42)$ & $69.95(37.49-103.71)$ & $0.456^{\mathrm{ns}}$ \\
\hline III & $57.53(34.06-112.95)$ & $60.73(22.30-103.04)$ & $53.14(30.72-125.08)$ & $0.234^{\mathrm{ns}}$ \\
\hline IV & $76.93(62.13-76.68)$ & $71.10(33.17-362.25)$ & $51.58(30.72-125.08)$ & $0.438^{\mathrm{ns}}$ \\
\hline
\end{tabular}


Cut-off values and prognostic significance of CEA and CA19-9. A higher BMI was shown to be significantly associated with higher plasma volumes. Compared with the normal weight patients, the patients with $\mathrm{BMI} \geq 24$ had $10-15 \%$ higher plasma volumes. The association of BMI with CEA and CA19-9 mass was then investigated. The CEA and CA19-9 mass did not change significantly with increasing BMI, except for CEA in stage. The proportion of patients with overall abnormal CEA and CA19-9 levels at each cut-off value was decreased with BMI (Table-15).

Table-16: Comparison between BMI and CEA evaluation for colorectal cancer $(\mathrm{n}=50)$

\begin{tabular}{|l|l|l|}
\hline \multirow{2}{*}{ CEA } & BMI \\
\cline { 2 - 3 } & Abnormal $(\mathbf{n}=\mathbf{1 1})$ & Normal $(\mathbf{n}=\mathbf{3 9})$ \\
\hline$\geq 7 \mathrm{ng} / \mathrm{ml}(\mathrm{n}=13)$ & 3 (True positive) & 10 (False positive) \\
\hline$<7 \mathrm{ng} / \mathrm{ml}(\mathrm{n}=37)$ & 8 (False negative) & 29 (True negative) \\
\hline
\end{tabular}

CEA evaluation for colorectal cancer, true positive 3 cases, false positive 10 cases, false negative 8 cases and true negative 29 cases in identification by BMI (Table-16).

Table-17: Comparison between BMI and CA 19-9 evaluation for colorectal cancer $(n=50)$

\begin{tabular}{|l|l|l|}
\hline \multirow{2}{*}{ CA 19-9 } & \multicolumn{2}{|l|}{ BMI } \\
\cline { 2 - 3 } & Abnormal $(\mathbf{n}=\mathbf{1 1})$ & Normal $(\mathbf{n}=\mathbf{3 9})$ \\
\hline$\geq 37 \mathrm{ng} / \mathrm{ml}(\mathrm{n}=10)$ & 3 (True positive) & 7 (False positive) \\
\hline$<37 \mathrm{ng} / \mathrm{ml}(\mathrm{n}=40)$ & 8 (False negative) & 32 (True negative) \\
\hline
\end{tabular}

CA 19-9 evaluation for colorectal cancer, true positive 3 cases, false positive 7 cases, false negative 8 cases and true negative 32 cases in identification by BMI (Table-17).

Table-18: Sensitivity, specificity, accuracy, positive and negative predictive values of the CEA and CA 19-9

\begin{tabular}{|c|c|c|}
\hline Validity test & CEA & CA 19-9 \\
\hline Sensitivity & 27.3 & 27.3 \\
\hline Specificity & 74.4 & 82.1 \\
\hline Accuracy & 64.0 & 70.0 \\
\hline Positive predictive value & 23.1 & 30.0 \\
\hline Negative predictive value & 78.4 & 80.0 \\
\hline
\end{tabular}

Sensitivity of BMI vs CEA was $27.3 \%$, specificity $74.4 \%$, accuracy $64.0 \%$, positive and negative predictive values were $23.1 \%$ and $78.4 \%$ respectively. Sensitivity of BMI vs CA $19-9$ was $27.3 \%$, specificity $82.1 \%$, accuracy $70.0 \%$, positive and negative predictive values were $30.0 \%$ and $80.0 \%$ respectively (Table-18).

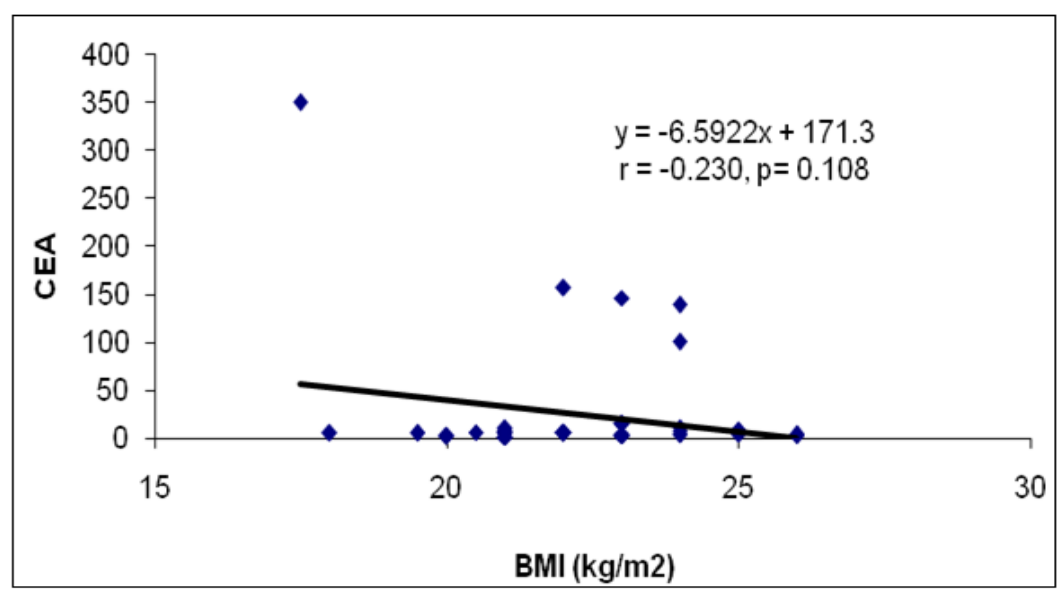

Fig-10: Scatter diagram showing negative correlation $(r=-0.230 ; p=0.108)$ between BMI and CEA of colorectal cancer 


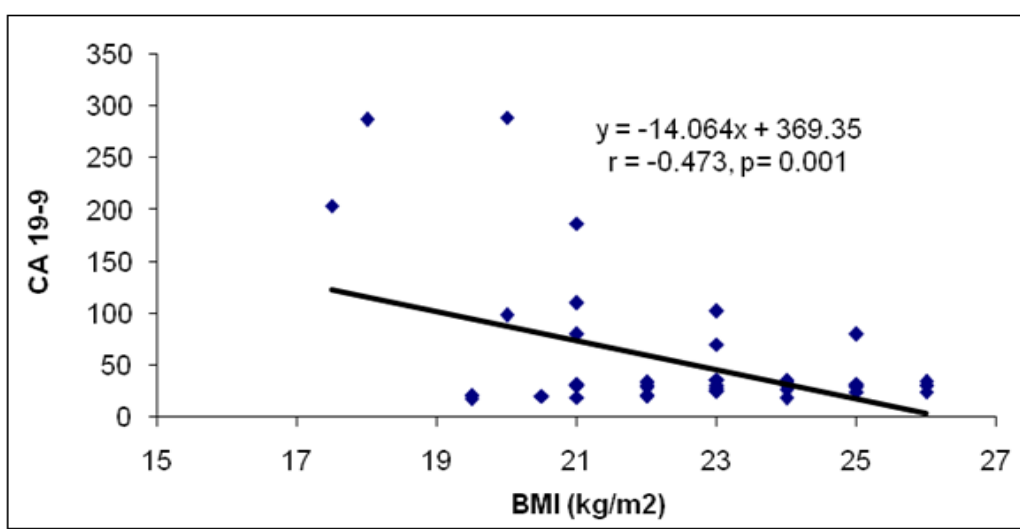

Fig-11: Scatter diagram showing negative correlation $(r=-0.437 ; p=0.001)$ between BMI and CA 19-9 of colorectal cancer

\section{DISCUSSION}

It was observed that majority patients belonged to age 41-50 years in both groups. The mean age was found $42.5 \pm 11.3$ years in CEA $(<7 \mathrm{ng} / \mathrm{ml})$ group and $40.7 \pm 12.1$ years in CEA $(\geq 7 \mathrm{ng} / \mathrm{ml})$ group. The mean difference was not statistically significant $(p>0.05)$ between the groups. Study showed that the most of the patients belonged to age $<60$ years in both groups, which was $52.4 \%$ in CEA $<7 \mathrm{ng} / \mathrm{ml}$ group and $53.4 \%$ in $\geq 7 \mathrm{ng} / \mathrm{ml}$ group. The difference was not statistically significant $(\mathrm{p}=0.881)$ [21]. In study of Park et al., [26], observed that the Mean age was found 63.0 years in CEA $<7 \mathrm{ng} / \mathrm{ml}$ group and 62.0 years in CEA $\geq 7 \mathrm{ng} / \mathrm{ml}$ group. The difference was not statistically significant $(p=0.131)$. In this study regarding sex distribution of the patients. It was observed that male was found 15 $(40.5 \%)$ in CEA $(<7 \mathrm{ng} / \mathrm{ml})$ group and $06(46.2 \%)$ in CEA $(\geq 7 \mathrm{ng} / \mathrm{ml})$ group. Male female difference was not statistically significant $(\mathrm{p}>0.05)$ between the groups. Compared the [22], study showed that male was found $133(58.6 \%)$ in CEA $(<7 \mathrm{ng} / \mathrm{ml})$ group and $39(53.4 \%)$ in CEA $(\geq 7 \mathrm{ng} / \mathrm{ml})$ group. Male female difference was not statistically significant $(\mathrm{p}>0.05)$ between the groups. Study revealed that male was found $55.4 \%$ in CEA $<7$ $\mathrm{ng} / \mathrm{ml}$ group and $54.6 \%$ in CEA $\geq 7 \mathrm{ng} / \mathrm{ml}$ group. Female was $42.6 \%$ and $45.4 \%$ in CEA $<7 \mathrm{ng} / \mathrm{ml}$ and CEA $\geq 7 \mathrm{ng} / \mathrm{ml}$ group respectively [23]. Male female difference was not statistically significant $(p>0.05)$ between the groups. Regarding histological type of the patients. It was observed that tubular adenocarcinoma was $27(73.0 \%)$ in CEA $(<7 \mathrm{ng} / \mathrm{ml})$ group and 10 (76.9\%) in CEA ( $\geq 7 \mathrm{ng} / \mathrm{ml})$ group. The difference was not statistically significant $(\mathrm{p}>0.05)$ between the groups. Tubular adenocarcinoma was $172(75.8 \%)$ in CEA $(<7$ $\mathrm{ng} / \mathrm{ml})$ group and $60(82.2 \%)$ in CEA $(\geq 7 \mathrm{ng} / \mathrm{ml})$ group [24]. The difference was not statistically significant ( $>0.05$ ) between the groups. It was observed that majority patients had tumor size $\leq 5 \mathrm{~cm}$ in both groups, which was $23(62.2 \%)$ in CEA $(<7 \mathrm{ng} / \mathrm{ml})$ group and 07 $(53.8 \%)$ in CEA $(\geq 7 \mathrm{ng} / \mathrm{ml})$ group. The difference was not statistically significant $(\mathrm{p}>0.05)$ between the groups. Study showed majority patients had tumor size $\leq 5 \mathrm{~cm}$ in both groups, which was $144(63.4 \%)$ in CEA $(<7 \mathrm{ng} / \mathrm{ml})$ group and $37(50.7 \%)$ in CEA $(\geq 7 \mathrm{ng} / \mathrm{ml})$ group [24]. The difference was not statistically significant $(\mathrm{p}>0.05)$ between the groups. It was observed that colon tumor was $16(43.2 \%)$ in CEA $(<7 \mathrm{ng} / \mathrm{ml})$ group and 07 $(53.8 \%)$ in CEA ( $\geq 7 \mathrm{ng} / \mathrm{ml})$ group. The difference was not statistically significant $(\mathrm{p}>0.05)$ between the groups. Colon tumor was $98(43.2 \%)$ in CEA $(<7 \mathrm{ng} / \mathrm{ml})$ group and $38(52.1 \%)$ in CEA $(\geq 7 \mathrm{ng} / \mathrm{ml})$ group [24]. The difference was not statistically significant $(p>0.05)$ between the groups. It was observed that peritoneal metastasis was $04(2.7 \%)$ in CEA $(<7 \mathrm{ng} / \mathrm{ml})$ group and $03(23.1 \%)$ in CEA $(\geq 7 \mathrm{ng} / \mathrm{ml})$ group. The difference was statistically significant $(\mathrm{p}<0.05)$ between the groups. Showed that peritoneal metastasis was 03 $(1.3 \%)$ in CEA $(<7 \mathrm{ng} / \mathrm{ml})$ group and $05(6.8 \%)$ in CEA $(\geq 7 \mathrm{ng} / \mathrm{ml})$ group [24]. The difference was statistically significant $(\mathrm{p}<0.05)$ between the groups. It was observed that liver metastasis was $02(5.4 \%)$ in CEA $(<7 \mathrm{ng} / \mathrm{ml})$ group and $02(15.4 \%)$ in CEA $(\geq 7 \mathrm{ng} / \mathrm{ml})$ group. The difference was not statistically significant ( $>0.05)$ between the groups. Chen et al., [24], observed that liver metastasis was $11(4.8 \%)$ in CEA $(<7 \mathrm{ng} / \mathrm{ml})$ group and $10(13.7 \%)$ in CEA $(\geq 7 \mathrm{ng} / \mathrm{ml})$ group. The difference was not statistically significant ( $p>0.05)$ between the groups. It was observed that in CEA $(<7 \mathrm{ng} / \mathrm{ml})$ group majority $19(51.4 \%)$ patients had TNM stage II and CEA ( $\geq 7 \mathrm{ng} / \mathrm{ml})$ group $07(53.8 \%)$ patients had TNM stage III. The difference was statistically significant $(\mathrm{p}<0.05)$ between the groups. Chen et al., [24], in CEA ( $<7 \mathrm{ng} / \mathrm{ml})$ group majority 100 (44.1\%) patients had TNM stage II and CEA ( $\geq 7 \mathrm{ng} / \mathrm{ml})$ group $30(41.1 \%)$ patients had TNM stage III. The difference was statistically significant $(\mathrm{p}<0.05)$ between the groups. It was observed that majority patients had moderate histological differentiation in both groups, which was $31(83.8 \%)$ in CEA $(<7 \mathrm{ng} / \mathrm{ml})$ group and 10 (76.9\%) in CEA ( $\geq 7 \mathrm{ng} / \mathrm{ml})$ group. The difference was not statistically significant $(\mathrm{p}>0.05)$ between the groups. Majority patients had moderate histological differentiation in both groups, which was 188 (82.8) in CEA $(<7 \mathrm{ng} / \mathrm{ml})$ group and $56(76.7 \%)$ in CEA $(\geq 7$ $\mathrm{ng} / \mathrm{ml}$ ) group [24]. The difference was not statistically significant $(p>0.05)$ between the groups. It was observed that mean age was found $43.7 \pm 10.5$ years in CA $19-9(<37 \mathrm{ng} / \mathrm{ml})$ group and $41.9 \pm 11.1$ years in CA $19-9(\geq 37 \mathrm{ng} / \mathrm{ml})$ group. The mean difference was not statistically significant $(p>0.05)$ between the groups. 
Most of the patients belonged to age $<60$ years in both groups, which was $112(47.7 \%)$ in CA $19-9<37 \mathrm{ng} / \mathrm{ml}$ group and $30(46.2 \%)$ in CA $19-9 \geq 37 \mathrm{ng} / \mathrm{ml}$ group [24]. The difference was not statistically significant $(\mathrm{p}=0.881)$. In study observed that mean age was found $63.2 \pm 0.7$ years in normal CA 19-9 and 64.2 \pm 1.6 years in high CA 19-9 [25]. Regarding sex distribution of the patients. It was observed that male was found 16 $(40.0 \%)$ in CA $19-9(<7 \mathrm{ng} / \mathrm{ml})$ group and $05(50.0 \%)$ in CA 19-9 $(\geq 37 \mathrm{ng} / \mathrm{ml})$ group. Male female difference was not statistically significant $(p>0.05)$ between the groups. Male was found $132(56.2 \%)$ in CA 19-9 (<7 $\mathrm{ng} / \mathrm{ml})$ group and $40(61.5 \%)$ in CA $19-9(\geq 37 \mathrm{ng} / \mathrm{ml})$ group [24]. Male female difference was not statistically significant $(p>0.05)$ between the groups. Similar results was found Yu et al. (2013) they observed that male was found $62.1 \%$ in normal CA $19-9$ and $60.7 \%$ in high CA 19-9. It was observed that majority patients had tumor size $\leq 5 \mathrm{~cm}$ in both groups, which was $25(62.5 \%)$ in CA $19-9(<37 \mathrm{ng} / \mathrm{ml})$ group and $05(50.0 \%)$ in CA 19-9 $(\geq 37 \mathrm{ng} / \mathrm{ml}$ ) group. The difference was not statistically significant $(\mathrm{p}>0.05)$ between the groups. Majority patients had tumor size $\leq 5 \mathrm{~cm}$ in both groups, which was $145(61.7 \%)$ in CA 19-9 (<37 ng/ml) group and 36 $(55.4 \%)$ in CA $19-9(\geq 37 \mathrm{ng} / \mathrm{ml})$ group [24]. The difference was not statistically significant $(\mathrm{p}>0.05)$ between the groups. In study observed that mean tumor size was found $4.8 \pm 0.1 \mathrm{~cm}$ in normal CA 19-9 and $6.1 \pm 0.3 \mathrm{~cm}$ in high CA 19-9 [25]. It was observed that colon tumor was $17(42.5 \%)$ in CA $19-9(<37 \mathrm{ng} / \mathrm{ml})$ group and $06(60.0 \%)$ in CA $19-9(\geq 37 \mathrm{ng} / \mathrm{ml})$ group. The difference was not statistically significant $(\mathrm{p}>0.05)$ between the groups. Chen et al.[24], colon tumor was $101(43.0 \%)$ in CA $19-9(<37 \mathrm{ng} / \mathrm{ml})$ group and 35 $(53.8 \%)$ in CA $19-9$ ( $\geq 37 \mathrm{ng} / \mathrm{ml})$ group. The difference was not statistically significant $(p>0.05)$ between the groups. Study was observed that colon tumor was found $76.7 \%$ in normal CA $19-9$ and $57.4 \%$ in high CA $19-9$ [25]. It was observed that peritoneal metastasis was 02 $(5.0 \%)$ in CA $19-9(<37 \mathrm{ng} / \mathrm{ml})$ group and $02(20.0 \%)$ in CA 19-9 $(\geq 37 \mathrm{ng} / \mathrm{ml})$ group. The difference was not statistically significant $(\mathrm{p}>0.05)$ between the groups. Chen et al. [24], peritoneal metastasis was 06 (2.6\%) in CA 19-9 (<37 ng/ml) group and $02(3.1 \%)$ in CA 19-9 $(\geq 37 \mathrm{ng} / \mathrm{ml})$ group. The difference was not statistically significant $(p>0.05)$ between the groups. Also support our findings they observed that perineural invasion was found $24.3 \%$ in normal CA $19-9$ and $41.0 \%$ in high CA 19-9 [25]. It was observed that liver metastasis was 03 $(7.5 \%)$ in CA 19-9 (<37 ng/ml) group and $01(10.0 \%)$ in CA 19-9 $(\geq 37 \mathrm{ng} / \mathrm{ml})$ group. The difference was not statistically significant $(\mathrm{p}>0.05)$ between the groups. Evidence [26], for the role of CEA in cancer dissemination was revealed in study by [27], who showed that the rate of liver metastasis in mice transplanted with colorectal tumours increased to $48 \%$ from $2 \%$ after CEA injection. In our study, serum CEA and CA 19-9 were found to be significantly elevated in the presence of distant metastasis, confirming that earlier report. In previous studies, elevated serum CA
19-9 was found to be related to distant metastasis [28], and elevated serum CEA and CA 19-9 were both found to be related to poor prognosis $[29,30]$ liver metastasis was $14(6.0 \%)$ in CA $19-9(<37 \mathrm{ng} / \mathrm{ml})$ group and 07 $(10.8 \%)$ in CA $19-9(\geq 37 \mathrm{ng} / \mathrm{ml})$ group. The difference was not statistically significant $(\mathrm{p}>0.05)$ between the groups. Regarding TNM staging of the patients, it was observed that in CA $19-9(<37 \mathrm{ng} / \mathrm{ml})$ group majority $19(47.5 \%)$ patients had TNM stage II and CA 19-9 ( $\geq 37 \mathrm{ng} / \mathrm{ml}$ ) group $06(60.0 \%)$ patients had TNM stage III. The difference was statistically significant $(\mathrm{p}<0.05)$ between the groups. In CA 19-9 $(<37 \mathrm{ng} / \mathrm{ml})$ group majority $100(42.6 \%)$ patients had TNM stage II and CA 19-9 ( $\geq 37 \mathrm{ng} / \mathrm{ml})$ group $30(46.2 \%)$ patients had TNM stage III [24]. The difference was statistically significant $(\mathrm{p}<0.05)$ between the groups. It was observed that almost two third $(62.5 \%)$ patients was found tubular adenocarcinoma in CA 19-9 $(<37 \mathrm{ng} / \mathrm{ml})$ group and $03(30.0 \%)$ in CA $19-9(\geq 37 \mathrm{ng} / \mathrm{ml})$ group. The difference was not statistically significant $(\mathrm{p}>0.05)$ between the groups. It was observed that majority patients had moderate histological differentiation in both groups, which was $32(80.0 \%)$ in CA 19-9 (<37 $\mathrm{ng} / \mathrm{ml})$ group and $09(90.0 \%)$ in CA $19-9(\geq 37 \mathrm{ng} / \mathrm{ml})$ group. The difference was not statistically significant $(p>0.05)$ between the groups. Majority patients moderate histological differentiation in both groups, which was $192(81.7 \%)$ in CA 19-9 $(<37 \mathrm{ng} / \mathrm{ml})$ group and $52(80.0 \%)$ in CA $19-9(\geq 37 \mathrm{ng} / \mathrm{ml})$ group [24]. The difference was not statistically significant $(p>0.05)$ between the groups. Study was observed that moderate differentiation was found $80.1 \%$ in normal CA $19-9$ and $85.2 \%$ in high CA 19-9 [25]. Cut-off values and prognostic significance of CEA and CA19-9. A higher BMI was shown to be significantly associated with higher plasma volumes. Compared with the normal weight patients, the patients with BMI $\geq 24$ had $10-15 \%$ higher plasma volumes. The association of BMI with CEA and CA19-9 mass was then investigated. The CEA and CA19-9 mass did not change significantly with increasing BMI, except for CEA in stage. The proportion of patients with overall abnormal CEA and CA19-9 levels at each cut-off value was decreased with BMI. Cut-off values and prognostic significance of CEA and CA19-9. A higher BMI was shown to be significantly associated with higher plasma volumes [24]. Compared with the normal weight patients, the patients with $\mathrm{BMI} \geq 24$ had $10-15 \%$ higher plasma volumes. The association of BMI with CEA and CA19-9 mass was then investigated. The CEA and CA19-9 mass did not change significantly with increasing BMI, except for CEA in stage. The proportion of patients with overall abnormal CEA and CA19-9 levels at each cut-off value was decreased with BMI. Both BMI and plasma volume were calculated as functions of height and weight [31]. Higher BMI was significantly associated with greater plasma volume. Patients with BMI of $\geq 27.5$ contained $10 \%$ to $15 \%$ larger plasma volumes relative to normal-weight patients. BMI correlated negatively with non-adjusted 
CEA concentration $(\gamma=-0.078, \mathrm{P}<0.001)$. However, this trend across different BMI categories did not reach statistical significance upon reanalysis of this association according to TNM category. Next, we examined the association between BMI and CEA mass. The CEA mass did not change significantly with increasing $\mathrm{BMI}$ at any stage $(\mathrm{P}=0.627,0.440,0.663$, and 0.346 for trend across the four pathologic stages.

In this current study it was observed that CEA evaluation for colorectal cancer, true positive 3 cases, false positive 10 cases, false negative 8 cases and true negative 29 cases in identification by BMI. CA 19-9 evaluation for colorectal cancer, true positive 3 cases, false positive 7 cases, false negative 8 cases and true negative 32 cases in identification by BMI. Showed there was no statistically significant difference in the proportion of patients with elevated CEA and CA19-9 levels by BMI category using different cut-off points [24]. In this series it was observed that sensitivity of BMI vs CEA was $27.3 \%$, specificity $74.4 \%$, accuracy $64.0 \%$, positive and negative predictive values were $23.1 \%$ and $78.4 \%$ respectively. Sensitivity of BMI vs CA $19-9$ was $27.3 \%$, specificity $82.1 \%$, accuracy $70.0 \%$, positive and negative predictive values were $30.0 \%$ and $80.0 \%$ respectively. Chen et al., [24], at a cut-off value of $2.5 \mathrm{ng} / \mathrm{ml}$ for preoperative CEA, the sensitivities of the lower range of normal weight $\left(\mathrm{BMI}<18.5 \mathrm{~kg} / \mathrm{m}^{2}\right.$ ), normal weight (BMI 18.5-24.0 $\mathrm{kg} / \mathrm{m}^{2}$ ) and overweight were $33.9,30.0$ and 20.0, respectively $(\mathrm{P}=0.136)$. At serum concentrations $>7.0$ $\mathrm{ng} / \mathrm{ml}$, preoperative CEA concentrations were predicted with a sensitivity of $23.0 \%$, specificity of $83.3 \%$, PPV of $60.0 \%$ and NPV of $51.2 \%$ in the obese group. In addition, the specificity, PPV and NPV were not significantly different in the analysis of CA19-9. Park et al., [26], subgroup analyses included 209 obese (BMI >27.5 $\mathrm{kg} / \mathrm{m}^{2}$ ) and 1,229 normal-weight (BMI $<23 \mathrm{~kg} / \mathrm{m}^{2}$ ) patients with a median follow-up period of 61 months (range, 1-181 months). At a cutoff value of $2.5 \mathrm{ng} / \mathrm{mL}$ for preoperative CEA, sensitivities were estimated as $74.5 \%$ and $63.6 \%$ in the normal-weight and obese groups, respectively ( $\mathrm{P}<0.001$ ). Specificity, PPV, and NPV were not significantly different between the two groups. At serum concentrations of $>7.0 \mathrm{ng} / \mathrm{mL}$ (positive test), preoperative CEA concentrations were predicted with a sensitivity of $40.9 \%$, specificity of $71.7 \%$, PPV of $14.5 \%$, and NPV of $91.2 \%$ in the obese group. Specificity and PPV were significantly lower in the obese group $(\mathrm{P}<0.05)$. In patients with high preoperative serum CEA, CEA surveillance showed $67.9 \%$ sensitivity, $96.1 \%$ specificity, a $92.3 \% \mathrm{PPV}$, and a $96.1 \%$ NPV for tumor recurrence [26, 33-35]. These findings, as well as the results of the current study showing that increased BMI negatively affects the diagnostic precision of the CEA test, pose an important query as to whether the measurement of preoperative CEA is less useful in obese patients. In cancer relapse patients, the sensitivity, specificity, and PPV of preoperative CEA at each cutoff point (2.5 or 7.0 $\mathrm{ng} / \mathrm{mL}$ ) was significantly reduced in the obese group. To effectively apply preoperative CEA measurement as a useful surveillance tool for tumor recurrence, it may be necessary to interpret the CEA concentrations of obese patients in a manner distinct from that of normalweight patients. In present study showed negative correlation $(r=-0.230 ; p=0.108)$ between BMI and CEA of colorectal cancer. Negative correlation $(r=-0.437$; $\mathrm{p}=0.001$ ) between BMI and CA 19-9 of colorectal cancer. In study of Shibutani et al., $[32,36]$, shown that the correlations between the preoperative CEA/CA19-9 levels and the site of recurrence and the correlations between the CEA/CA19-9 levels at the time of relapse and the site of recurrence are provided. No significant differences in these parameters were observed based on the levels of the tumor markers.

\section{Conclusion}

In conclusion, the study inverse correlation was found between Body Mass Index with CEA and CA -19-9 in colorectal cancer patient, but Sensitivity and Specificity was low. The combination of preoperative CEA and CA19-9 levels was useful for predicting prognosis in patients with colorectal cancer. This information contributed to the identification of patients who were at high risk of recurrence and were recommended to receive adjuvant chemotherapy after potentially curative surgery. Furthermore, the combination of the preoperative levels of CEA and CA19-9 was also useful for detecting and exclude a recurrence or metastasis of colorectal cancer after a potentially curative operation.

\section{REFERENCES}

1. Amino N, Kuro R, Yabu Y, Takai Si, Kawashima M, Morimoto S, Ichihara K, Miyai K, Kumahara Y. Elevated levels of circulating carcinoembryonic antigen in hypothyroidism. The Journal of Clinical Endocrinology \& Metabolism. 1981 Mar 1;52(3):457-62.

2. Ballesta AM, Molina R, Filella X, Jo J, Giménez $\mathrm{N}$. Carcinoembryonic antigen in staging and follow-up of patients with solid tumors. Tumor biology. 1995;16(1):32-41.

3. Balslev IB, Pedersen M, Teglbjaerg PS, HanbergSoerensen F, Bone J, Jacobsen NO, Overgaard J, Sell A, Bertelsen K, Hage E, Fenger C. Postoperative radiotherapy in Dukes' B and C carcinoma of the rectum and rectosigmoid: a randomized multicenter study. Cancer. $1986 \mathrm{Jul}$ 1;58(1):22-8.

4. Banez LL, Hamilton RJ, Partin AW, Vollmer RT, Sun L, Rodriguez C, Wang Y, Terris MK, Aronson WJ, Presti JC, Kane CJ. Obesity-related plasma hemodilution and PSA concentration among men with prostate cancer. Jama. 2007 Nov 21;298(19):2275-80.

5. Basbug M, Arikanoglu Z, Bulbuller N, Cetinkaya Z, Aygen E, Akbulut S, Satici O. Prognostic value 
of preoperative CEA and CA 19-9 levels in patients with colorectal cancer. Hepato Gastroenterology-Current Medical and Surgical Trends. 2011 Apr;58(106):400-405.

6. Baxter NN, Morris AM, Rothenberger DA, Tepper JE. Impact of preoperative radiation for rectal cancer on subsequent lymph node evaluation: a population-based analysis. International Journal of Radiation Oncology* Biology* Physics. 2005 Feb 1;61(2):426-31.

7. Beets-Tan RG, Beets GL. Rectal cancer: review with emphasis on MR imaging. Radiology. 2004 Aug;232(2):335-46.

8. Birgisson H, Pahlman L, Gunnarsson U, Glimelius B. Adverse effects of preoperative radiation therapy for rectal cancer: long-term follow-up of the Swedish Rectal Cancer Trial. J Clin Oncol. 2005 Dec 1;23(34):8697-705.

9. Birgisson H, Talbäck M, Gunnarsson U, Påhlman L, Glimelius B. Improved survival in cancer of the colon and rectum in Sweden. European Journal of Surgical Oncology (EJSO). 2005 Oct 1;31(8):84553.

10. Bulut I, Arbak P, Coskun A, Balbay O, Annakkaya AN, Yavuz O, Gülcan E. Comparison of serum CA 19.9, CA 125 and CEA levels with severity of chronic obstructive pulmonary disease. Medical principles and practice. 2009;18(4):289-93.

11. Cancer Research Campaign. Cancer of the large bowel. Factsheet 18. London: CRC, 1993.

12. Swedish Rectal Cancer Trial. Improved survival with preoperative radiotherapy in resectable rectal cancer. New England Journal of Medicine. 1997 Apr 3;336(14):980-7.

13. Chang IH, Ahn SH, Han JH, Kim TH, Kim YS, Myung SC. The clinical significance in healthy men of the association between obesity related plasma hemodilution and tumor marker concentration. The Journal of urology. 2009 Feb 1;181(2):567-73.

14. Chen W, Liu Q, Tan SY, Jiang YH. Association between carcinoembryonic antigen, carbohydrate antigen 19-9 and body mass index in colorectal cancer patients. Molecular and Clinical Oncology. 2013 Sep 1;1(5):879-86.

15. Duffy MJ. Carcinoembryonic antigen as a marker for colorectal cancer: is it clinically useful?. Clinical chemistry. 2001 Apr 1;47(4):624-30.

16. Fukuda I, Yamakado M, Kiyose H. Influence of smoking on serum carcinoembryonic antigen levels in subjects who underwent multiphasic health testing and services. Journal of medical systems. 1998 Apr 1;22(2):89-93.

17. Heald RJ, Ryall RD. Recurrence and survival after total mesorectal excision for rectal cancer. The Lancet. 1986 Jun 28;327(8496):1479-82.

18. Herbeth B, Bagrel A. A study of factors influencing plasma CEA levels in an unselected population. Oncodevelopmental biology and medicine: the journal of the International Society for Oncodevelopmental Biology and Medicine. 1980;1(4-5):191-8.

19. Holm T, Johansson H, Cedermark B, Ekelund G, Rutqvist LE. Influence of hospital- and surgeonrelated factors on outcome after treatment of rectal cancer with or without preoperative radiotherapy. British journal of surgery. 1997 May;84(5):65763.

20. Hostetter RB, Augustus LB, Mankarious R. Carcinoem-bryonic antigen as a selective enhancer of colorectal cancer metastasis. J Natl Cancer Inst, 1990; 82:380-385.

21. Lee SH, Ahn BK, Baek SU, Chang HK. BRAF mutation in multiple primary cancer with colorectal cancer and stomach cancer. Gastroenterol Rep (Oxf), 2013;1(1):70-74.

22. Lin PC, Lin JK Lin CC. Carbohydrate antigen 199 is a valuable prognostic factor in colorectal cancer patients with normal levels of carcinoembryonic antigen and may help predict lung metastasis. Int $\mathbf{J}$ Colorectal Dis, 2012; 27:1333-1338.

23. Marrelli D, Caruso S, Pedrazzani C, Neri A, Fernandes E, Marini M. CA19-9 serum levels in obstructive jaundice: clinical value in benign and malignant conditions. Am J Surg, 2009;198:333-339.

24. Chen CC, Yang SH, Lin JK, Lin TC, Chen WS, Jiang JK. Is it reasonable to add preoperative serum level of CEA and CA19-9 to staging for colorectal cancer?. J Surg Res, 2005;124(2):169174.

25. Yu H, Son GM, Jon YG. The clinical significance of preoperative serum levels of carbohydrate antigen 19-9 in colorectal cancer. J Korean Surg Soc, 2013;84, 231-237.

26. Park IJ, Choi GS, Lim KH, Kang BM, Jun SH. Serum carcinoembryonic antigen monitoring after curative resection for colorectal cancer: clinical significance of the preoperative level. Annals of surgical oncology. 2009 Nov 1;16(11):3087-93.

27. McLaughlin R, O'Hanlon D, Kerin M, Kenny P, Grimes H, Given HF. Are elevated levels of the tumour marker CA19-9 of any clinical significance?-An evaluation. Irish journal of medical science. 1999 Apr 1;168(2):124-6.

28. Påhlman L, Bohe M, Cedermark B, Dahlberg M, Lindmark G, Sjödahl R, Öjerskog B, Damber L, Johansson R. The Swedish rectal cancer registry. British Journal of Surgery: Incorporating European Journal of Surgery and Swiss Surgery. 2007 Oct;94(10):1285-92.

29. Socialstyrelsens statistikdatabaser. http://www.socialstyrelsen.se/statistik/statistikdata bas

30. Staab HJ, Anderer FA, Stumpf E, Hornung A, Fischer R, Kleninger G. Eighty-four potential second-look operations based on sequential carcinoembryonic antigen determinations and clinical investigations in patients with recurrent 
gastrointestinal cancer. The American journal of surgery. 1985 Feb 1;149(2):198-204.

31. Wanebo HJ, Rao B, Pinsky CM, Hoffman RG, Stearns M, Schwartz MK, Oettgen HF. Preoperative carcinoembryonic antigen level as a prognostic indicator in colorectal cancer. New England Journal of Medicine. 1978 Aug 31;299(9):448-51.

32. Wibe A, Eriksen MT, Syse A, Tretli S, Myrvold HE, Søreide O. Effect of hospital caseload on long- term outcome after standardization of rectal cancer surgery at a national level. British Journal of Surgery: Incorporating European Journal of Surgery and Swiss Surgery. 2005 Feb;92(2):21724.

33. Williams NS, Bulstrode CJK, O'Connell PR. Bailey \& loves's: Short practice of surgery. $26^{\text {th }}$ edition. Hodder Education, an Hachette UK company; 2013:1153-1165.

34. Williams NS, Bulstrode CJK, O'Connell PR. Bailey \& loves's: Short practice of surgery. $25^{\text {th }}$ edition. Hodder Education, an Hachette UK company; 2008; 1164-1227.

35. Witherspoon LR, Shuler SE, Alyea K, Husserl FE. Carcinoembryonic antigen: assay following heat compared with perchloric acid extraction in patients with colon cancer, non-neoplastic gastrointestinal diseases, or chronic renal failure. Journal of nuclear medicine: official publication, Society of Nuclear Medicine. 1983 Oct;24(10):916-21.

36. Yang SH, Lin JK, Lai CR, Chen CC, Li AF, Liang WY, Jiang JK. Risk factors for peritoneal dissemination of colorectal cancer. Journal of surgical oncology. 2004 Sep 15;87(4):167-73. 